\title{
Neurotoxicity mechanism of Ochratoxin A
}

\author{
Fahimeh Nourbakhsh', Elahe Tajbakhsh ${ }^{2}$ \\ ${ }^{1}$ Medical Toxicology Research Centre, Faculty of Medicine, Mashhad University of Medical Sciences, Mashhad, Iran; \\ ${ }^{2}$ Departments of Microbiology, Faculty of Basic Sciences, Shahrekord Branch, Islamic Azad University, Shahrekord, Iran
}

*Corresponding author: Fahimeh Nourbakhsh, Medical Toxicology Research Centre, Faculty of Medicine, Mashhad University of Medical Sciences, Mashhad, Iran. Email: Fahimeh_Nourbakhsh@yahoo.com

Submitted: 9 November 2020; Accepted: 13 January 2021; Published: 27 April 2021

(c) 2021 Codon Publications

OPEN ACCESS (C) (i) () REVIEW ARTICLE

\begin{abstract}
Mycotoxins, such as Ochratoxins, are widely distributed in nature and are common contaminants of human foodstuffs. Ochratoxins are a group of mycotoxins produced by a wide range of molds. Ochratoxin A (OTA), the most prominent member of this toxin family, is produced by various Aspergillus and Penicillium species. OTA is frequently found in foods such as cereals, oleaginous seeds, coffee, and meat products. This mycotoxin has been described as teratogenic, genotoxic, carcinogenic, and immunotoxic, and has been proven to be a potent neurotoxin. In the present study, the neurotoxicological perspective of OTA was reviewed and discussed. The main possible mechanisms of neurotoxicity are oxidative DNA, protein and lipid damage, and apoptosis. However, further studies are needed to conclude the exact neurotoxicity mechanism of OTA and find the approaches that reduce the neurotoxicity induced by OTA.
\end{abstract}

Keywords: brain; mycotoxins; neurotoxicity; Ochratoxin A

\section{Introduction}

Mycotoxins are a group of secondary metabolites that are often produced by fungi such as Penicillium and Aspergillus (Frisvad et al., 2018; Magan and Aldred, 2007). The greatest threats to these toxins are related to food, especially cereals. The various diseases threatening these mycotoxins range from simple allergic responses to immune suppression and cancer (Pitt, 2000). Mycotoxins are the most important fungal metabolites that, due to their high prevalence, can damage human and animal health. Ochratoxin A (OTA) is one of the most important mycotoxins that have an interactive effect on cells and widely affect human and animal health. Produced by A. ochraceus and P. verrucosum OTA (Lund and Frisvad, 2003), it is able to enter the human food chain through the introduction of livestock products (Magan and Aldred, 2005), the animal feeding of contaminated grains, as well as the consumption of food products (Otteneder and Majerus, 2000). OTA has little solubility in water and is highly soluble in organic solvents. Thus, the uptake of OTA from biological membranes is easily accomplished. This toxin is structurally solid and white in color and is also heat-resistant. Analysis of OTA's structure reveals a polyketide-derived secondary metabolite that contains a dihydrocoumarin moiety coupled to $1-\beta$-phenylalanine (Phe), derived from the shikimic acid pathway, by an amide bond (Huffman et al., 2010).

Reportedly, OTA is detectable in most blood samples even at very low levels in most people. OTA is known as a cause of Balkan Endemic Nephropathy (Agarwal et al., 2020). For example, OTA was detected in 58\% of human milk (as high as $6.6 \mu \mathrm{g} / \mathrm{l}$ ). OTA also was detected in the urine of pregnant women and $100 \%$ of human blood samples (maximum $0.04 \mu \mathrm{g} / \mathrm{L}$ ). According to these studies, infants are likely exposed to the level of $1 \mathrm{ng} / \mathrm{kg}$ body weight, which is above the recommended dose per day (Skaug et al., 2001). This mycotoxin, in particular, is a succinate inhibitor in the electron transport chain and 
is capable of causing neurogenic disorders, especially Parkinson's disease, through a mechanism similar to MPTP (1-methyl-4-phenyl-1,2,3,6-tetrahydropyridine) and rotenone. The International Agency for Cancer Research has classified OTA as a type 2B carcinogen, and it has been shown to be capable of causing DNA damage as well (Sueck et al., 2019). This toxin affects organs, such as the kidney and the liver, bypassing the placenta, causing inappropriate effects of mutagenesis and suppression of the immune system, especially in monocytes and lymphocyte function (Köhler et al., 2002). As noted, ochratoxins consist of an isocoumarin moiety and a phenylalanine moiety linked by an amide bond (Figure 1). According to research, OTA is chlorinated, Ochratoxin B is not chlorinated, and Ochratoxin $\mathrm{C}$ is the ethyl ester of OTA, OTB, and OTC, which is less toxic and less common. The most important focus group is the OTA. OTA is introduced with the following specifications $(\mathrm{C} 20 \mathrm{H} 18 \mathrm{ClNO6}$; with melting point: $168-173^{\circ} \mathrm{C}$ and molecular weight: 403.8) (Petzinger and Ziegler, 2000).

Therefore, the most important mycotoxins are effective in neurotoxicity mentioned in Table 1 . Given the importance and scope of mycotoxins, we investigate the mechanism of neurotoxicity induced by OTA as one of the most important mycotoxins. In terms of temperature tolerance, OTA is resistance for 3 hours of high temperature $\left(121^{\circ} \mathrm{C}\right)$ and pressure steam sterilization (Blanc et al., 1998; van der Stegen et al., 2001). Ochratoxin is classified as a Class $2 \mathrm{~B}$ substance by the International Agency for Research on Cancer (IARC) and World Health Organization (WHO) (Pfohl-Leszkowicz and Manderville, 2007; Rindi et al., 2018). Various studies,

(A)<smiles>C[C@@H]1Cc2c(Cl)cc(C(=O)N[C@@H](Cc3ccccc3)C(=O)O)c(O)c2C(=O)O1</smiles>

(B)<smiles>C[C@@H]1Cc2ccc(C(=O)N[C@@H](Cc3ccccc3)C(=O)O)c(O)c2C(=O)O1</smiles>

(C)<smiles>CCOC(=O)[C@H](Cc1ccccc1)NC(=O)c1cc(Cl)c2c(c1O)C(=O)O[C@@H](C)C2</smiles>

Figure 1. Chemical structures of (A) Ochratoxin A, (B) Ochratoxin B and (C) Ochratoxin C. Red color related to dihydroisocoumarin ring and dark blue related to phenylalanine part.

Table 1. Important mycotoxins-induced neurotoxicity.

\begin{tabular}{|c|c|c|c|c|c|}
\hline Mycotoxins & Species producer & Chemical Formula & Metabolism & Exposure & Neurotoxicity Mechanism \\
\hline T-2 Toxin & $\begin{array}{l}\text { Fusarium. } \\
\text { sporotichioides }\end{array}$ & $\mathrm{C}_{24} \mathrm{H}_{34} \mathrm{O}_{9}$ & $\begin{array}{l}\text { Ester hydrolysis } \\
\text { Hydroxylation }\end{array}$ & $\begin{array}{l}\text { Corn, Wheat } \\
\text { Barley, Rice }\end{array}$ & $\begin{array}{l}\text { Mitogen-activated protein } \\
\text { kinases (MAPKs) }\end{array}$ \\
\hline $\begin{array}{l}\text { Macrocyclic } \\
\text { Trichothecenes }\end{array}$ & $\begin{array}{l}\text { Stachybotrys } \\
\text { chartarum }\end{array}$ & $\mathrm{C}_{27} \mathrm{H}_{29} \mathrm{O}_{10}$ & $\begin{array}{l}\text { Peptidyl Transferase } \\
\text { Inhibition }\end{array}$ & $\begin{array}{l}\text { Food stuffs or in } \\
\text { livestock feeds }\end{array}$ & $\begin{array}{l}\text { DNA damage MAPKs } \\
\text { Inflammation } \\
\text { Sesquiterpenoid } \\
\text { compound }\end{array}$ \\
\hline Fumonisin B1 & $\begin{array}{l}\text { Fusarium } \\
\text { verticillioides }\end{array}$ & $\mathrm{C}_{34} \mathrm{H}_{59} \mathrm{NO}_{15}$ & $\begin{array}{l}\text { Changes in Lipid } \\
\text { Metabolism }\end{array}$ & Orally via food & $\begin{array}{l}\text { Inflammation } \\
\text { Apoptosis } \\
\text { Isoflavonoid compound }\end{array}$ \\
\hline Ochratoxin A & $\begin{array}{l}\text { Aspergillus } \\
\text { ochraceus }\end{array}$ & $\mathrm{C}_{20} \mathrm{H}_{18} \mathrm{CINO}_{6}$ & $\begin{array}{l}\text { Phenylalanine t-RNA } \\
\text { inhibition }\end{array}$ & $\begin{array}{l}\text { Coffee, Wheat } \\
\text { Barley, Rice }\end{array}$ & $\begin{array}{l}\text { Inflammation } \\
\text { Apoptosis } \\
\text { MAPKs }\end{array}$ \\
\hline
\end{tabular}


including in vivo studies and in vitro studies, have investigated the toxic effects of ochratoxin. Nowadays, ochratoxin is very prominent among other toxins and despite its toxicity to organs such as kidney and liver, it also causes extensive toxicity to nerve tissues (Fuchs et al., 2001). Different toxicity mechanisms have been suggested for OTA, such as cell death and oxidative stress. Extensive studies have been carried out on the development of digestive, urinary, immune, and reproductive toxicity by Ochratoxin. Hence, in the present study, we tried to review all possible articles from the neurotoxicological perspective of OTA.

\section{Regulation of Ochratoxins in Foods}

The fungi responsible for OTA contamination vary from crop to crop and from place to place.

The general rule, succinctly stated by authors, is "Ochratoxin A is produced by Penicillium verrucosum in cereal grains in cold climates, by A. carbonarius in grapes, wines, and vine fruits, and by $A$. ochraceus sometimes in coffee beans" (Seabra et al., 2020). However, $P$. verrucosum has recently been found in cereals in warmer climates: Italy, Spain, France, and Portugal (Czerwiecki, 2001). In general, the average concentration of OTA is reported to range from 0.1 to $100 \mathrm{ng}$ per gram of foodstuffs of plant origin (Dhanshetty and Banerjee, 2019). Due to the proliferation of mycotoxin infections, such as aflatoxins and Ochratoxin, here are some cases of contamination with Ochratoxin. According to European Union (EU) reports and surveillance, the restrictions on Ochratoxin include $5 \mu \mathrm{g} / \mathrm{kg}$ in raw cereal grains, $10 \mu \mathrm{g} / \mathrm{kg}$ in dried vine fruits (raisins), and $3 \mu / \mathrm{kg}$ in processed cereal foods (FAO). The EU also announced restrictions on the amount of Ochratoxins in wine $(2.0 \mu \mathrm{g} / \mathrm{kg})$, grape juice $(2.0 \mu \mathrm{g} / \mathrm{kg})$, and coffee $(10.0 \mu \mathrm{g} / \mathrm{kg}$ for instant coffee, $5.0 \mu \mathrm{g} / \mathrm{kg}$ for roasted coffee) since April of 2005 (FAO, 2005). The cases reviewed in 2005 were reevaluated in 2006. Other European countries have also introduced restrictions on the amount of Ochratoxin in coffee beans. In Italy, for example, this number was reported at $8 \mu \mathrm{g} / \mathrm{kg}$ (FAO, 2005). The sensitivities shown to control pollution in coffee are due to its high economic value and the importance of its export to developing countries (Iriondo-DeHond et al., 2019). Because coffee beans are stored in inappropriate places, it is not possible to accurately detect contamination. According to the opinions and forecasts of the European Coffee Federation, the maximum permitted level of Ochratoxin in green coffee is $5 \mu / \mathrm{kg}$, which could reject 18\% of transactions in South Africa (Romani et al., 2000). After the Joint Food and Agricultural Organization (FAO)/WHO Expert Committee on Food Additives (JECFA), an expert body which provides scientific advice to the CAC, repeatedly dealt with OTA in 1991, 1995,
2001, and 2007, a maximum limit of $5 \mu \mathrm{g} / \mathrm{kg}$ with respect to wheat, barley, and rye has been recently established under the Codex General Standard for Contaminants and Toxins in Food and Feed (Ropejko and Twarużek, 2019). In contrast, the United States has not individually reported dietary restrictions for Ochratoxin levels (Yu et al., 2019). However, the absence of these restrictions has a significant impact on the economy of each country (Lee et al., 2019). Numerous exposures to diets with Ochratoxin contamination remains a significant source of OTA exposure in humans (Huong et al., 2019). Background studies on average levels of OTA in humans eating a typical diet have, however, only shown modest elevations in urinary OTA levels, well under the $2.0 \mathrm{ppb}$ limit of detection level used by the commercial lab to test these patients (Czerwiecki, 2001; Duarte et al., 2010; Fazekas et al., 2002).

\section{Toxicokinetics of OTA}

\section{Absorption}

Studies show that OTA can affect plasma membrane micro domains as one of the important factors in intestinal transport and thereby alter the uptake through the intestinal epithelium (Maresca et al., 2001). The amount of uptake varies by species, for example, up to $60 \%$ uptake in pigs, which is much more than in rodents (StuderRohr et al., 2000). Studies have reported lower plasma levels of Ochratoxin B protein than OTA, which indicates less toxicity of Ochratoxin B (Coronel et al., 2010; Galtier et al., 1981; Heussner and Bingle, 2015). According to studies, the bioavailability of oral OTA in humans was the highest at $93 \%$. Nonionic and mono-ionic forms of OTA have high reabsorption capacity through the stomach and proximal jejunum (Ricci et al., 2021). As regards of OTA uptake in intestinal lumen, MRP2 (multidrug resistance-associated protein) can decrease OTA absorption (Berger et al., 2003). In addition to the above, studies show that OTA inhibits intestinal absorption and reduces the rate of reabsorption of the intestinal epithelium and intestinal transport activity (Maresca et al., 2001; Ranaldi et al., 2009).

\section{Distribution}

One of the distribution systems of OTA is through binding to plasma proteins (Studer-Rohr et al., 2000). OTA has a high potential for binding to plasma albumin. But, studies have reported a small amount of OTA in blood erythrocytes located on the subdomain (Perry et al., 2004). Some proteins with molecular masses (more than $20 \mathrm{kDa}$ ) bind to albumin. These proteins were lower in concentration than albumin. Several studies have been 
performed on the distribution of OTA in tissues (Biró et al., 2002). Studies of traceability have reported that $0.04 \mu \mathrm{g} / \mathrm{l}(100 \%)$ OTA was detected in blood samples. It was indicated that OTA is detected at $0.9 \mu \mathrm{g} / \mathrm{l}(58 \%)$ in Norwegian human milk samples, which is lower than reported in plasma samples in different studies (Skaug et al., 2001). Similar studies in Sweden reported blood plasma levels of OTA from 0.09 to $0.9 \mu \mathrm{g} / \mathrm{l}$ and also $21 \%$ $(1.8 \mu \mathrm{g} / \mathrm{l})$ in breast milk samples of nephropathy patients. In a Tunisian study, both blood and food samples from nephropathy patients had significantly higher OTA levels than healthy controls (Commission, 1998). In a Taiwanese study, excretion of OTA in urine of diabetes mellitus patients was significantly higher than in control patients, and patients with other types of nephropathy (Hsieh et al., 2004). These show correlation rather than causality, but taken together they suggest that exposure to high OTA levels is associated with damage to various organs (Chen and Wu, 2017; Skaug et al., 2001).

\section{Excretion}

Excretion of OTA is often by secretion through the renal tubes and partly due to glomerular filtration due to the ability of OTA to bind to albumin (Il'ichev et al., 2002; Perry et al., 2003). Studies show that OAT1 is one of the most important receptors in the kidney and OAT3 in the liver and brain, which plays a major role in the reabsorption of toxins from the blood into the tissue (Jung et al., 2001). Studies of the reabsorption of this toxin in renal nephrons have reported both active and inactive pathways (Berger et al., 2003; Leier et al., 2000). Enterohepatic circulation is another fecal excretion of OTA, which enhances the slow elimination of toxicants from the body (Schrickx et al., 2006). BCRP (Breast cancer resistance protein) transporters were known as important for intestinal excretion of OTA (Skaug et al., 2001). In animals, especially in rodents, the role of entero-hepatic circulation of OTA has been demonstrated. In addition, the conjugated form of the toxin is excreted tthrough bile in the studied rat specimens. Moreover, studies have described different concentrations of toxin in milk, besides that breast milk may have been at the highest level in the first few days after delivery (Boudra et al., 2007).

\section{Mechanisms of Toxicity}

\section{Oxidative stress}

Oxidative stress means an imbalance between free radicals and antioxidants. Free radicals contain oxygen and can react with other molecules (Gautier et al., 2001). Free radicals have the potential to produce large chemical reactions in the body called oxidation reactions. These reactions are often harmful and may interfere with cellular communication. Oxidative stress is recognized as one of the most important factors associated with diseases (Schaaf et al., 2002). The most important cellular damage they cause is damage to DNA, proteins, lipid, and even lipid peroxidation (using $\mathrm{Fe}^{3+}$ as cofactor). According to recent reports by researchers, oxidative stress is one of the modes of actions in various toxicities of Ochratoxin (Zhu et al., 2017).

Ochratoxin is able to increase the expression of metallothionein and induce oxidative stress in the cell by decreasing the amount of superoxide dismutase (Poor et al., 2014). On the other hand, it has been suggested that reactive oxygen species (ROS) production is not only the main mechanism of OTA toxicity but also that OTA decreases the cellular antioxidant agents and increases the toxic effects of it. The following can affect and decrease activator protein 1 (AP-1) and nuclear factor erythroid 2-related factor 2 (Nrf2) activation (MarinKuan et al., 2005). Cavin et al. showed that OTA can also inhibit the expression of Nrf2 protein, its translocation into the cell nucleus, as well as its binding to DNA in rat liver and kidney cells (Cavin et al., 2006).

Based on the results of the abovementioned studies, it is important that the levels of reactive nitrogen species are also increased in the samples affected by Ochratoxin. High levels of nitric oxide (NO) because of the reaction with $\mathrm{O}_{2}$ may cause nitrosative stress. However, studies in the field of carcinogenicity of Ochratoxin show that the mechanism of creation of carcinogenic effects is independent of the mechanism of oxidative stress. One of the important neurotoxicity mechanisms of Ochratoxin is the inhibition of Nrf2 transcription, which subsequently increases neurotoxicity (Limonciel and Jennings, 2014). Activation of the oxidative esterification mechanism causes lipid peroxidation, DNA oxidative damage, and phototoxic stress (Boesch-Saadatmandi et al., 2008).

In 2001, a study showed that there was a significant decrease in SOD, GSH, CAT, and GSPx levels in the groups treated with Ochratoxin. Based on these studies, we conclude that ROS plays an important role in the occurrence of OTA-induced neurotoxicity and that GSH levels play an important role in limiting neurotoxicity of this mycotoxin (Uetsuka, 2011; Zhang et al., 2009).

OTA has also been reported to inhibit succinatedependent electron transfer in the electron transport chain, but at higher concentrations will also inhibit electron transport at complex I, suggesting mitochondrial toxicity (Babayan et al., 2019). The developing brain appears to be very susceptible to the deleterious effects of OTA. The calculation in this research suggested that OTA 
significantly affects the striatal DA metabolism enzymes involved in the metabolism of DNA and regional brain oxidative stress. Initial studies were conducted in year 2 on the teratogenicity of Ochratoxin and brain injury. In this research, it was indicated that exposure to OTA in pregnant mice $(5 \mathrm{mg} / \mathrm{kg})$ on gestation day 9 leads to the exencephalic in offspring (Lagace et al., 2006). Such differences between cell lines might be due in part to the complex nature of protein expression and functional regulation required during the intracellular signaling of apoptosis. Because inhibition of the expression of propyl 4-hydoxylase is known to attenuate upregulation of neuronal cells associated with ROS, it leads to apoptosis and loss of mitochondria membrane potential (Zhang et al., 2009).

\section{Cell apoptosis}

OTA can directly cause cell death through apoptosis and necrosis (Lioi et al., 2004). However, nanomolar level of Ochratoxin can also induce cell changes in the expression of different genes and can be one of the most likely causes of apoptosis in the cells (Gekle et al., 2000; Sorrenti et al., 2013). Changes in the transcriptional level of many genes, such as GADD153, GADD45, p53, and clusterin, are involved in causing DNA damage and also contribute to cell death. (Lühe et al., 2003; Qi et al., 2014).

Studies on rat liver and kidney cells identified Ochratoxin as one of the most important tumor promoters and also showed activation and expression of proteins involved in apoptosis such as MAPK, ERK, p38, and JNK (Horvath et al., 2002). Another study suggested apoptotic cell death in mouse hippocampal HT22 cells (Yoon et al., 2009). It is clear that OTA-induced cytotoxicity and proteome response can be indicative of neurodegeneration. OTA-induced neurotoxicity seems to be, at least party, mediated by apoptosis, and OTA may contribute to the pathogenesis of neurodegenerative diseases (e.g., Alzheimer's and Parkinson's disease) in which apoptotic processes are centrally involved (Zhang et al., 2009). It can be said that Ochratoxin can induce necrosis, cell damage, apoptosis, and ultimately brain cell death (Weidenbach et al., 2000; Zhang et al., 2009). Neurotoxicity in human astrocytes through apoptosis and intracellular calcium overload was also reported in recent researches (Park et al., 2019).

\section{Protein synthesis inhibition}

Another very important mechanism of OTA toxicity is the inhibition of protein synthesis in cells (Weidenbach et al., 2000). The mechanism of inhibition in cellular protein synthesis may also be associated with an effect on normal cells (Al-Anati and Petzinger, 2006). By this mechanism, OTA inhibits as well as decreases cell growth and proliferation. It has been shown that phenylalanine t-RNA inhibition is one of the main mechanisms of OTA. Although it has been shown that phenylalanine moiety of OTA has a major role as a competitor between phenylalanine and the toxin, isocoumarin structure is more important in this interaction than the phenylalanine moiety because modification of the isocoumarin structure has a significant impact on this action (Xiong et al., 2020). Studies, of course, have provided some evidence to support the importance of OTA isocoumarin structures. It is important to note that studies by researchers have shown that the effects of OTA on phenylalanine hydroxylase and phenylalanine t-RNA synthase occur after high doses of Ochratoxin. Although nonspecific methods of inhibiting protein synthesis have been proposed, OTA is particularly effective in the transcription of many proteins (Hong et al., 2002).

\section{Calcium homeostasis}

It's clear that impaired calcium homeostasis can effects on cell cytotoxicity. Various studies of the effect of intrathecal and in vivo OTA toxin on calcium homeostasis were investigated (Benesic et al., 2000). Some studies have shown that cells treated with Ochratoxin after lipid peroxidation is highly prone to calcium permeability. Some authors indicated that impairment of the endoplasmic reticulum membrane is directly related to calcium homeostasis of cells. This in turn leads to abnormal cell proliferation. According to the results of some studies in 1989, OTA can inhibit ATP-dependent calcium uptake by up to $45 \%$.

In addition, studies show that impairment of calcium homeostasis induced by toxicity with OTA is related to impairment of endoplasmic reticulum membranes and also through increased lipid peroxidation. It was indicated that OTA effects affects renal endoplasmic reticulum calcium pump activity and also decreases renal mitochondrial state-3 respiration and calcium uptake (Pagliassotti et al., 2016). In line with previous studies, authors indicated that OTA can affect the modulation of intracellular calcium levels in syrian embryonic fibroblast (SHE), and ultimately, by disrupting extracellular calcium, may produce a long-lasting signal of calcium channel damage (Park et al., 2019).

\section{Cell autophagy}

Autophagy is a response to adaptation under conditions of cellular damage. In fact, autophagy and mitophagy 
adapt and control a variety of diseases and damage to the cell (Aleo et al., 1991; Xing et al., 2019). Studies show that one of the most important functions of OTA is cellular destruction through autophagy (Shen et al., 2014). As noted, mitophagy is one of the most important and complex mechanisms of mitochondrial elimination (Ariafar et al., 2020). A study in 2014 noted activation of autophagy and mitophagy pathways by ochratoxin. This study refers to the Nix role as selective and central autophagy receptor. It was indicated that Nix-deficient HEK293 cells occur after the presence of OTA. Moreover, OTA is able to upregulated bad and AIF proteins as proapoptotic factors that all leads to an increase in cell death (Novak, 2012; Zhu et al., 2017).

\section{Influence on mitosis}

Although various studies have described the toxicity of OTA as a carcinogenic agent, the direct effect of the toxin on DNA has not been discussed. Studies in human renal cells suggest that OTA may be a promoter for tumor formation and an apoptotic inducer by impairing cell division regulation. It was indicated that OTA plays an important role as an inhibitor of histone acetyl transferase (HAT) tumble microtubular system and asymmetric cell division (Adler et al., 2009). In addition, OTA inhibits HATs with an epigenetic mechanism which conducted to kidney tumors inductions and genetic mutability (Adler et al., 2009; Mally, 2012). OTA apoptosis mechanisms and cell signaling pathways shows in Figure 2.

\section{Neurotoxicity due to OTA, Which Interferes with the Development of Diseases}

\section{Motor disorder and Parkinson's disease}

Various studies have shown neurotoxicity effects of OTA; for example, the study of Belmadani and co-authors show the cytotoxicity of OTA $(403 \mathrm{ng} / 10 \mu \mathrm{l})$ in various parts of the brain tissue, "Due to the increased rate of lactate dehydrogenase (LDH)," especially in cerebellum (34.4\%) as the main OTA-target (Crago et al., 2003). In addition, necrotic cells were increased in the ventral mesencephalon (VM) and cerebellum due to the regional
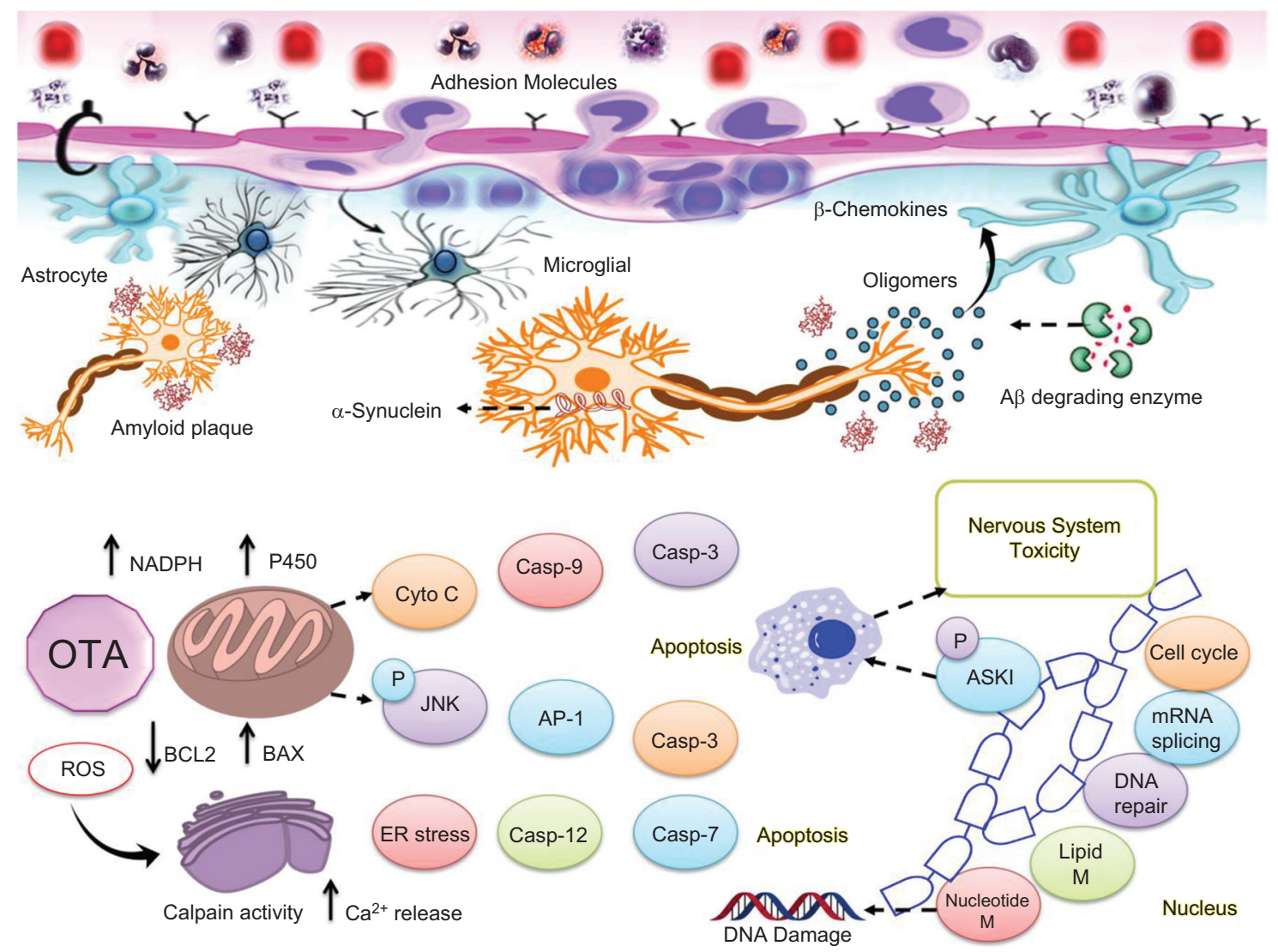

Figure 2. OTA-induced apoptosis and cell signaling. OTA induced the increase of NADPH and P450 enzyme, which activates the caspase signaling pathway and induces apoptosis. The increase of ROS caused mitochondria and endoplasmic reticulum oxidative stress, inducing calcium release and inhibiting the cell cycle, mRNA splicing, DNA replication, lipid and nucleotide metabolism. All of these could lead to cell apoptosis. 
selectivity of OTA (Sava et al., 2006). This concept is in line with another research of Sava et al. that shows low level of OTA to induce Parkinsonism in male mice. It was revealed that OTA induced neurodegenerative diseases and brain dysfunction; low-level administration of OTA leads to depletion of striatal dopamine, increased oxidative stress, and decreased intensity of tyrosine hydroxylase immunoreactivity (TH+) (Sava et al., 2006). Proliferating NSC exhibited a greater vulnerability to the toxin than differentiated neurons despite robust DNA repair and antioxidant responses. Such a result is unexpected since DNA repair systems are typically more active and efficient in proliferating cells than in post-mitotic differentiated cells (Hameed et al., 2017).

In line with these studies, Masao Tamaru and co-authors showed that OTA affects cerebral hemispheres, cortex and subjacent white matter, hippocampus, and amygdale of pregnant mice on day 11 of gestation. It was indicated that total content of noradrenaline (NA), dopamine (DA) 5-hydroxytryptamine (5-HT) were directly affected by OTA (Sava et al., 2007). It has also been proved that sub-chronic treatment of OTA affects the young adult rat brain. Furthermore ( $289 \mathrm{mg} / \mathrm{kg} / 48 \mathrm{~h}$ dose), injection of OTA also affects free amino-acid concentrations; in particular, it plays a role in increasing the amount of phenylalanine and necrotic cells with pyknotic nucleus (Aimone et al., 2006).

DNA damage, lipid peroxidation, and superoxide dismutase (SOD) increase cellular toxicity in various parts of the brain (Sava et al., 2006). It was demonstrated that low dose of OTA ( $10 \%$ of the $\left.\mathrm{LD}_{50}\right)$ leads to DNA repairmen and up-regulation of anti-oxidant systems. The study also examined the distribution of toxins in different parts of the brain; based on the results, cerebellum has the highest absorption of OTA, half-life of elimination (T1/2) in midbrain was lower than other regions of the brain, and OGG1 activities increased in all parts of the brain (Yoon et al., 2009). Inhibition of protein synthesis, competition with phenylalanine in the amino acylation reaction of phenylalanine-tRNA conducted to disruption in produce of dopamine and catecholamine. An increase in the ratio of acetylcholine to dopamine in the basal glands of the brain causes symptoms of tremor, muscle stiffness, and slowness of movement (Sueck et al., 2019).

\section{Hippocampal Toxicity and Memory Impairment}

The clinical significance of the impact of OTA on hippocampal neurogenesis in adult brain relates to its potential effect on cognitive function, provided that effects on neurogenesis observed in vitro can be reproduced in vivo. It has been suggested that generation of new neurons throughout life is related to the formation of temporal associations in memory (Aimone et al., 2006). These findings confirm the previous researches demonstrate the partial protective effect of melatonin in OTA toxicity (Delibas et al., 2003). Overall, these results lead to speculation that OTA exposure may contribute to impaired hippocampal neurogenesis in vivo, resulting in depression and memory deficits, conditions reported to be linked to mycotoxin exposure in humans (Sava et al., 2007). In addition to cognitive deficits, a significant association between psychological disorders such as melancholic depression with mycotoxin exposure has been reported (Crago et al., 2003). Interestingly, impaired hippocampal neurogenesis may underlie depression, as suggested by the observation that certain antidepressants (selective serotonin uptake inhibitors) stimulate hippocampal neurogenesis. In light of the critical role played by HP in cognitive function, and the importance of neurogenesis in this structure throughout life, the impact of mycotoxins on hippocampal neural stem/progenitor cells (NSC) is highly relevant from both molecular pathogenesis and clinical perspectives (Sava et al., 2006).

As mentioned, $0.01-100 \mathrm{mg} / \mathrm{mL}$ of OTA decreases the both proliferating and neurogenesis of hippocampal neural cell (Sava et al., 2007). Ongoing studies are investigating the impact of sub acute and chronic OTA administration on hippocampal-dependent learning paradigms and correlating these cognitive deficits with impaired hippocampal neurogenesis in vivo. All reports can be based on studies of mycotoxins-induced brain toxicity, resulting in depression and cognitive deficits (Gordon and Cantor, 2004). The potential harm caused by environmental exposure to OTA in terms of its effects on neuronal cell viability and proteome profiles using mouse hippocampal HT22 and human neuroblastoma SH-SY5Y cells has been investigated. Generation of ROS was detected in OTA-treated SH-SY5Y and HT22 cells; however, caspase activation and an increase in p53 phosphorylation were only detected in HT22 cells, even though OTA treatment caused oxidative stress in both cell lines (Otteneder and Majerus, 2000). Upregulation of propyl 4-hydroxylase was reported in HT22 cells after treatment with OTA (Agarwal et al., 2020). All this shows that OTA would contribute to the pathogenesis of neurodegenerative diseases (e.g., Alzheimer's and Parkinson's disease). Due to the toxic effects of OTA in brain cells, it has been shown that there is relationship between OTA toxicity and glial reactivity. Changes in astrocyte integrity and the cell cytoskeletal were also seen in OTA-treated mice (Fuchs et al., 2001). A peroxisome proliferator-activated receptor gamma (PPAR- $\gamma$ ) agonist blocked OTA-induced neurotoxicity by inhibiting $\mathrm{AP}$ and NF- $\mathrm{KB}$ activation in cultured rat embryonic midbrain cells (Hong et al., 2002). 


\section{Changes in Brain Tissue}

Studies have shown that OTA has immunological, genotoxic, teratogenic, especially nephrotoxic, as well as carcinogenic and neurogenic effects. Due to teratogenic effects of OTA, it can have several histopathological changes in the brain tissue (Delibas et al., 2003). A similar study was conducted to investigate the rate of uptake of OTA into brain tissue in 1998. Increasing the duration of exposure of animals increased the amount of OTA absorbed in the brain tissue. The study also showed that OTA had a significant effect on tyrosine and phenylalanine content. Various necrotic cells with pyknotic nucleus were reported by these researchers (Sava et al., 2007). Similar studies in encephalic embryos showed extensive destruction of the brain tissue due to exposure to OTA and also $0.50 \mathrm{mg} / \mathrm{kg}$ treatments resulted in degeneration of lenticular fibers, adhesion of anterior epithelial cell of the lens with the cornea, narrowing of the anterior chamber, degeneration, detachment of upper retinal layers, and extension of damaged retinal layers over optic nerve fibers (Delibas et al., 2003). All studied brain regions shows that apoptosis in the substantia nigra (SN), striatum and hippocampus and other brain regions, significantly decreased oxyguanosine glyosylase (OGG1) (Sava et al., 2006). In contrast to OGG1, other indices of oxidative stress (lipid peroxidation and SOD activity) exhibited a monophasic increase over time throughout the brain (Sava et al., 2006). Due to the widespread toxicity of OTA and the tissue damage noted, several studies have been reported on the antioxidant effects of the substances. Aantioxidant substances for the treatment OTA toxicity are listed in Table 2. Given the importance of OTA and the mechanisms of brain toxicity and neurodegenerative diseases through different mechanisms, further studies are recommended.

\section{Conclusion}

OTA has been described as a teratogenic, genotoxic, carcinogenic, immunotoxic, and also neurotoxic mycotoxin.

Table 2. The effect of antioxidant substances and food components in Ochratoxin toxicity.

\begin{tabular}{|c|c|c|c|}
\hline Substances & Antioxidant mechanism & Organs & Results/conclusion \\
\hline $\begin{array}{l}\text { Vitamins E ( } \alpha \text {-tocopherol) } \\
\text { Vitamins C (ascorbic acid) }\end{array}$ & $\begin{array}{l}\downarrow \text { Peroxyl radical scavenger DNA adduct } \\
\downarrow \text { Cytochrome P450 isoenzymes }\end{array}$ & $\begin{array}{l}\text { BME-UV1 } \\
\text { MDCK } \\
\text { Human cell line } \\
\text { Mice kidney } \\
\text { HepG2 cells } \\
\text { Neuronal cells }\end{array}$ & $\begin{array}{l}\text { Function as a peroxyl radical scavenger } \\
\text { that terminates chain reactions is well } \\
\text { documented. Retinol }(A) \text {, ascorbic acid (C) } \\
\text { act as superoxide anion scavengers. }\end{array}$ \\
\hline $\begin{array}{l}\text { Phenolic Compounds } \\
\text { (EGCG) } \\
\text { (ECG) } \\
\text { (C3G) }\end{array}$ & $\begin{array}{l}\downarrow \text { ROS production } \\
\downarrow \text { DNA fragmentation and Tumor } \\
\text { angiogenesis }\end{array}$ & $\begin{array}{l}\text { LLC-PK1 } \\
\text { HepG2 cells } \\
\text { Rat Liver, Kidney, and } \\
\text { Brain }\end{array}$ & $\begin{array}{l}\text { Cytoprotective effects of catechins. C3G } \\
\text { is the most effective compound that } \\
\text { counteracts the effects of OTA. LPE exerts } \\
\text { a potent antioxidant capacity such as } \\
\text { flavonoids. }\end{array}$ \\
\hline Vitis vinifera & $\begin{array}{l}\downarrow \text { DNA adduct } \\
\downarrow \text { ROS production }\end{array}$ & Rat Liver and Kidney & $\begin{array}{l}\text { Berry and leaf juice } \\
\text { of Vitis vinifera Hepatic and } \\
\text { Renal damage. }\end{array}$ \\
\hline Lycopene & $\begin{array}{l}\downarrow \text { Damage of lipids, } \\
\downarrow \text { Proteins, and DNA }\end{array}$ & $\begin{array}{l}\text { Rat Kidney } \\
\text { Brain cortex }\end{array}$ & $\begin{array}{l}\text { Glutathione peroxidase (GPx) } \\
\text { activity and GSH levels }\end{array}$ \\
\hline Glutathione & $\begin{array}{l}\downarrow \text { Genotoxicity } \\
\downarrow \text { DNA adduct }\end{array}$ & $\begin{array}{l}\text { Rabbit Kidney } \\
\text { OK } \\
\text { Proximal tubular } \\
\text { epithelial cells }\end{array}$ & $\begin{array}{l}\text { Oxidative stress by increasing free thiols in } \\
\text { kidney, BSO, ACIVICIN }\end{array}$ \\
\hline $\begin{array}{l}\text { Zinc } \\
\text { Mg } \\
\text { Selenium }\end{array}$ & $\begin{array}{l}\downarrow \text { SOD } \\
\downarrow \text { ROS production } \\
\downarrow \text { DNA adduct } \\
\downarrow \text { Apoptosis }\end{array}$ & HepG2 cells & $\begin{array}{l}\text { Zinc is an essential component of } \mathrm{Cu} / \mathrm{Zn} \\
\text { SOD1 to increase OTA toxicity and it can } \\
\text { be used in the diet }\end{array}$ \\
\hline $\begin{array}{l}\text { Antioxidant Mixture } \\
\text { (CoQ10) } \\
\text { (Mel) } \\
\text { (L-carnitine) } \\
\text { (N-acetyl cysteine) }\end{array}$ & $\begin{array}{l}\downarrow \text { ROS production } \\
\downarrow \text { Apoptosis }\end{array}$ & $\begin{array}{l}\text { Mice Liver } \\
\text { Rat Liver, Kidney, } \\
\text { and Brain }\end{array}$ & $\begin{array}{l}\text { Affected Malondialdehyde (MDA) levels } \\
\text { in the plasma and GSH levels. Involved in } \\
\text { mitochondrial oxidative phosphorylation } \\
\text { system and ameliorates OTA toxicity }\end{array}$ \\
\hline
\end{tabular}

BME-UV1: Bovine Mammary Epithelial Cells, MDCK: Madin Darby Canine Kidney Cells, HepG2: liver (HepG2) cells, EGCG: Epigallocatechin Gallate, C3G: Cyanidin 3-O- $\beta$-D-glucoside, LLC-PK1: LLC-PK1, LPE: Liquorice Plant Extract, OK: Opossum Kidney Cells, BSO: Buthionine Sulfoximine, ACIVICIN: alpha amino-3-chloro-4, 5-dihydro-5-isoxazole acetic acid, SOD1: Superoxide Dismutase, CoQ10: Coenzyme Q10. 
Various studies have shown regional selectivity of OTA neurotoxicity, especially by LDH or increased mitochondrial SOD activity. Therefore, noradrenaline (NA), dopamine (DA) 5-hydroxytryptamine (5-HT) can directly affected by OTA, which can be conducted to brain toxicity motor disorder and memory impairment.

The underlying mechanisms of neurotoxicity of the OTA still need to be elucidated. Recent advances mainly support oxidative DNA, protein, lipid damage and loss of cell membrane integrity induced by ROS production of OTA.

Given the potential chronic human exposure to the mycotoxins, a better understanding of the toxicokinetics and the mechanisms of neurotoxicity of the OTA is necessary to provide adequate human risk assessments.

\section{Conflict of interest}

The authors declare that there are no conflicts of interest.

\section{References}

Adler, M., Müller, K., Rached, E., Dekant, W. and Mally, A., 2009. Modulation of key regulators of mitosis linked to chromosomal instability is an early event in ochratoxin A carcinogenicity. Carcinogenesis 30: 711-719. http://dx.doi.org/10.1093/carcin/ bgp049

Agarwal, P., Singh, D., Raisuddin, S. and Kumar, R., 2020. Amelioration of ochratoxin-A induced cytotoxicity by prophylactic treatment of N-Acetyl-L-Tryptophan in human embryonic kidney cells. Toxicology 429: 152324. http://dx.doi. org/10.1016/j.tox.2019.152324

Aimone, J.B., Wiles, J. and Gage, F.H., 2006. Potential role for adult neurogenesis in the encoding of time in new memories. Nature Neuroscience 9: 723. http://dx.doi.org/10.1038/nn1707

Al-Anati, L. and Petzinger, E., 2006. Immunotoxic activity of ochratoxin A. Journal of Veterinary Pharmacology and Therapeutics 29: 79-90. http://dx.doi.org/10.1111/j.1365-2885.2006.00718.x

Aleo, M.D., Wyatt, R.D. and Schnellmann, R.G., 1991. Mitochondrial dysfunction is an early event in ochratoxin A but not oosporein toxicity to rat renal proximal tubules. Toxicology and Applied Pharmacology 107: 73-80. http://dx. doi.org/10.1016/0041-008X(91)90332-9

Ariafar, S., Oftadeh Harsin, A., Fadaiie, A., Mahboobian, M.M. and Mohammadi, M., 2020. Toxicity effects of mycotoxins and autophagy: a mechanistic view. Toxin Reviews12: 1-11. http:// dx.doi.org/10.1080/15569543.2019.1711416

Babayan, N., Tadevosyan, G., Khondkaryan, L., Grigoryan, R., Sarkisyan, N., Haroutiounian, R. and Stopper, H., 2019. Ochratoxin A induces global DNA hypomethylation and oxidative stress in neuronal cells in vitro. Mycotoxin Research 36: 1-9. http://dx.doi.org/10.1007/s12550-019-00370-y
Benesic, A., Mildenberger, S. and Gekle, M., 2000. Nephritogenic ochratoxin A interferes with hormonal signalling in immortalized human kidney epithelial cells. Pflügers Archiv 439: 278287. http://dx.doi.org/10.1007/s004240050941

Berger, V., Gabriel, A.-F., Sergent, T., Trouet, A., Larondelle, Y. and Schneider, Y.-J., 2003. Interaction of ochratoxin A with human intestinal Caco-2 cells: possible implication of a multidrug resistance-associated protein (MRP2). Toxicology Letters 140: 465476. http://dx.doi.org/10.1016/S0378-4274(03)00043-2

Biró, K., Solti, L., Barna-Vetró, I., Bagó, G., Glávits, R., Szabó, E. and Fink-Gremmels, J., 2002. Tissue distribution of ochratoxin A as determined by HPLC and ELISA and histopathological effects in chickens. Avian Pathology 31: 141-148. http://dx.doi. org/10.1080/03079450120118621

Blanc, M., Pittet, A., Muñoz-Box, R. and Viani, R., 1998. Behavior of ochratoxin A during green coffee roasting and soluble coffee manufacture. Journal of Agricultural and Food Chemistry 46: 673-675. http://dx.doi.org/10.1021/jf9707703

Boesch-Saadatmandi, C., Loboda, A., Józkowicz, A., Huebbe, P., Blank, R., Wolffram, S., et al. 2008. Effect of ochratoxin A on redox-regulated transcription factors, antioxidant enzymes and glutathione-S-transferase in cultured kidney tubulus cells. Food and Chemical Toxicology 46: 2665-2671. http://dx.doi. org/10.1016/j.fct.2008.04.023

Boudra, H., Barnouin, J., Dragacci, S. and Morgavi, D., 2007. Aflatoxin M1 and ochratoxin A in raw bulk milk from French dairy herds. Journal of Dairy Science 90: 3197-3201. http://dx. doi.org/10.3168/jds.2006-565

Cavin, C., Delatour, T., Marin-Kuan, M., Holzhäuser, D., Higgins, L., Bezencon, C., et al. 2006. Reduction in antioxidant defenses may contribute to ochratoxin A toxicity and carcinogenicity. Toxicological Sciences 96: 30-39. http://dx.doi.org/10.1093/ toxsci/kfl169

Chen, C. and Wu, F., 2017. The need to revisit ochratoxin A risk in light of diabetes, obesity, and chronic kidney disease prevalence. Food and Chemical Toxicology 103: 79-85. http://dx.doi. org/10.1016/j.fct.2017.03.001

Commission., C.A., 1998. Position paper on ochratoxin A. Food and Agriculture Organization of the United Nations, Rome, Italy, 1998. Available at: http://www.who.int/fsf/ Chemicalcontaminants/ochratoxinpp99_14.

Coronel, M., Sanchis, V., Ramos, A. and Marin, S., 2010. Ochratoxin A: presence in human plasma and intake estimation. Food Science and Technology International 16: 5-18. http://dx. doi.org/10.1177/1082013209353359

Crago, B.R., Gray, M.R., Nelson, L.A., Davis, M., Arnold, L. and Thrasher, J.D., 2003. Psychological, neuropsychological, and electrocortical effects of mixed mold exposure. Archives of Environmental Health: An International Journal 58: 452-463. http://dx.doi.org/10.3200/AEOH.58.8.452-4.63

Czerwiecki, L., 2001. Ochratoxin A and other mycotoxins in Polish cereals and foods. Mycotoxin Research 17: 125-128. http://dx. doi.org/10.1007/BF03036419

Delibas, N., Altuntas, I., Yonden, Z. and Ozcelik, N., 2003. Ochratoxin A reduces NMDA receptor subunits $2 \mathrm{~A}$ and $2 \mathrm{~B}$ concentrations in rat hippocampus: partial protective effect of 
melatonin. Human \& Experimental Toxicology 22: 335-339. http://dx.doi.org/10.1191/0960327103ht357oa

Dhanshetty, M. and Banerjee, K., 2019. Simultaneous direct analysis of aflatoxins and ochratoxin A in cereals and their processed products by ultra-high performance liquid chromatography with fluorescence detection. Journal of AOAC International. 6: 1666-1672. http://dx.doi.org/10.5740/jaoacint.19-0048

Duarte, S., Pena, A. and Lino, C., 2010. A review on ochratoxin A occurrence and effects of processing of cereal and cereal derived food products. Food Microbiology 27: 187-198. http://dx.doi. org/10.1016/j.fm.2009.11.016

FAO, 2004. Worldwide regulations for mycotoxins in food and feed in 2003. Available at: http://www.fao.org/documents/show_cdr. asp?url_file=/docrep/007/y5499e/y5499e0f.htm

FAO, 2005. Reducing ochratoxin A in coffee. Available at: http:// www.coffee-ota.org/proj_background.asp.

Fazekas, B., Tar, A. and Zomborszky-Kovács, M., 2002. Ochratoxin A contamination of cereal grains and coffee in Hungary in the year 2001. Acta Veterinaria Hungarica 50: 177188. http://dx.doi.org/10.1556/avet.50.2002.2.7

Frisvad, J.C., Møller, L.L., Larsen, T.O., Kumar, R. and Arnau, J., 2018. Safety of the fungal workhorses of industrial biotechnology: update on the mycotoxin and secondary metabolite potential of Aspergillus niger, Aspergillus oryzae, and Trichoderma reesei. Applied Microbiology and Biotechnology 102: 94819515. http://dx.doi.org/10.1007/s00253-018-9354-1

Fuchs, E., Binder, E., Schatzmayr, G., Heidler, D., Klimitsch, A. and Krska, R., 2001. Monitoring of residues of ochratoxin A in blood and kidney of chicken using HPLC-FLD. Mycotoxin Research 17: 142-145. http://dx.doi.org/10.1007/BF03036423

Galtier, P., Alvinerie, M. and Charpenteau, J., 1981. The pharmacokinetic profiles of ochratoxin A in pigs, rabbits and chickens. Food and Cosmetics Toxicology 19: 735-738. http://dx.doi. org/10.1016/0015-6264(81)90528-9

Gautier, J.-C., Holzhaeuser, D., Markovic, J., Gremaud, E., Schilter, B.T. and Turesky, R.J., 2001. Oxidative damage and stress response from ochratoxin A exposure in rats. Free Radical Biology and Medicine 30: 1089-1098. http://dx.doi.org/10.1016/ S0891-5849(01)00507-X

Gekle, M., Schwerdt, G., Freudinger, R., Mildenberger, S., Wilflingseder, D., Pollack, V., et al. 2000. Ochratoxin A induces JNK activation and apoptosis in MDCK-C7 cells at nanomolar concentrations. Journal of Pharmacology and Experimental Therapeutics 293: 837-844.

Gordon, W.A. and Cantor, J.B., 2004. The diagnosis of cognitive impairment associated with exposure to mold. Advances in Applied Microbiology 55: 361. http://dx.doi.org/10.1016/ S0065-2164(04)55014-1

Hameed, M.R., Khan, M.Z., Saleemi, M.K., Khan, A., Akhtar, M., Hassan, Z.-U. and Hussain, Z., 2017. Study of ochratoxin A (OTA)-induced oxidative stress markers in broiler chicks. Toxin Reviews 36: 270-274. http://dx.doi.org/10.1080/15569543.2017 .1303780

Heussner, A.H. and Bingle, L.E., 2015. Comparative ochratoxin toxicity: a review of the available data. Toxins 7: 4253-4282. http:// dx.doi.org/10.3390/toxins7104253
Hong, J.T., Lee, M.K., Park, K.S., Jung, K.M., Lee, R.D., Jung, H.K., et al. 2002. Inhibitory effect of peroxisome proliferatoractivated receptor gamma agonist on ochratoxin A-induced cytotoxicity and activation of transcription factors in cultured rat embryonic midbrain cells. Journal of Toxicology and Environmental Health Part A 65: 407-418. http://dx.doi. org/10.1080/15287390252808073

Horvath, A., Upham, B.L., Ganev, V. and Trosko, J.E., 2002. Determination of the epigenetic effects of ochratoxin in a human kidney and a rat liver epithelial cell line. Toxicon 40: 273-282. http://dx.doi.org/10.1016/S0041-0101(01)00219-7

Hsieh, M.F., Chiu, H.Y., Lin-Tan, D.T. and Lin, J.L., 2004. Does human ochratoxin A aggravate proteinuria in patients with chronic renal disease? Renal Failure 26: 311-316. http://dx. doi. org/10.1081/JDI-200026744

Huffman, J., Gerber, R. and Du, L., 2010. Recent advancements in the biosynthetic mechanisms for polyketide-derived mycotoxins. Biopolymers 93: 764-776. http://dx.doi.org/10.1002/bip.21483

Huong, B.T.M., Tuyen, L.D., Madsen, H., Brimer, L., Friis, H. and Dalsgaard, A., 2019. Total dietary intake and health risks associated with exposure to aflatoxin B1, ochratoxin A and fuminisins of children in Lao Cai Province, Vietnam. Toxins 11: 638. http:// dx.doi.org/10.3390/toxins11110638

Il'ichev, Y.V., Perry, J.L. and Simon, J.D., 2002. Interaction of ochratoxin A with human serum albumin. Preferential binding of the dianion and $\mathrm{pH}$ effects. The Journal of Physical Chemistry B 106: 452-459. http://dx.doi.org/10.1021/jp012314u

Iriondo-DeHond, A., Garcia, N.A., Fernandez-Gomez, B., Guisantes-Batan, E., Escobar, F.V., Blanch, G.P., et al. 2019. Validation of coffee by-products as novel food ingredients. Innovative Food Science \& Emerging Technologies 51: 194-204. http://dx.doi.org/10.1016/j.ifset.2018.06.010

Jung, K.Y., Takeda, M., Kim, D.K., Tojo, A., Narikawa, S., Yoo, B.S., et al. 2001. Characterization of ochratoxin A transport by human organic anion transporters. Life Sciences 69: 2123-2135. http://dx.doi.org/10.1016/S0024-3205(01)01296-6

Köhler, H., Heller, M., Erler, W., Müller, G., Rosner, H. and Gräfe, U., 2002. Effect of ochratoxin A and ochratoxin C on the monocyte and lymphocyte function. Mycotoxin Research 18: 169-172. http://dx.doi.org/10.1007/BF0294.6089

Lagace, D.C., Yee, J.K., Bolaños, C.A. and Eisch, A.J., 2006. Juvenile administration of methylphenidate attenuates adult hippocampal neurogenesis. Biological Psychiatry 60: 1121-1130. http:// dx.doi.org/10.1016/j.biopsych.2006.04.009

Lee, H.J., Gu, B.-J., Ganjyal, G. and Ryu, D., 2019. Reduction of ochratoxin A in direct steam injected oat-based infant cereals with baking soda. Food Control 96: 441-444. http://dx.doi. org/10.1016/j.foodcont.2018.10.001

Leier, I., Hummel-Eisenbeiss, J., Cui, Y. and Keppler, D., 2000. ATPdependent para-aminohippurate transport by apical multidrug resistance protein MRP2. Kidney International 57: 1636-1642. http://dx.doi.org/10.104.6/j.1523-1755.2000.00007.x

Limonciel, A. and Jennings, P., 2014. A review of the evidence that ochratoxin A is an Nrf2 inhibitor: implications for nephrotoxicity and renal carcinogenicity. Toxins 6: 371-379. http://dx.doi. org/10.3390/toxins6010371 
Lioi, M., Santoro, A., Barbieri, R., Salzano, S. and Ursini, M., 2004. Ochratoxin A and zearalenone: a comparative study on genotoxic effects and cell death induced in bovine lymphocytes. Mutation Research/Genetic Toxicology and Environmental Mutagenesis 557: 19-27. http://dx.doi.org/10.1016/j.mrgentox.2003.09.009

Lühe, A., Hildebrand, H., Bach, U., Dingermann, T. and Ahr, H.-J., 2003. A new approach to studying ochratoxin A (OTA)-induced nephrotoxicity: expression profiling in vivo and in vitro employing cDNA microarrays. Toxicological Sciences 73: 315-328. http://dx.doi.org/10.1093/toxsci/kfg073

Lund, F. and Frisvad, J.C., 2003. Penicillium verrucosum in wheat and barley indicates presence of ochratoxin A. Journal of Applied Microbiology 95: 1117-1123. http://dx.doi. org/10.104.6/j.1365-2672.2003.02076.x

Magan, N. and Aldred, D., 2005. Conditions of formation of ochratoxin A in drying, transport and in different commodities. Food Additives and Contaminants 22: 10-16. http://dx.doi. org/10.1080/02652030500412154

Magan, N. and Aldred, D., 2007. Why do fungi produce mycotoxins? Mycology Series 25: 121. http://dx.doi. org/10.1201/9781420020984.ch7

Mally, A., 2012. Ochratoxin A and mitotic disruption: mode of action analysis of renal tumor formation by ochratoxin A. Toxicological Sciences 127: 315-330. http://dx.doi.org/10.1093/ toxsci/kfs105

Maresca, M., Mahfoud, R., Pfohl-Leszkowicz, A. and Fantini, J., 2001. The mycotoxin ochratoxin A alters intestinal barrier and absorption functions but has no effect on chloride secretion. Toxicology and Applied Pharmacology 176: 54-63. http://dx. doi.org/10.1006/taap.2001.9254

Marin-Kuan, M., Nestler, S., Verguet, C., Bezencon, C., Piguet, D., Mansourian, R., et al. 2005. A toxicogenomics approach to identify new plausible epigenetic mechanisms of ochratoxin A carcinogenicity in rat. Toxicological Sciences 89: 120-134. http:// dx.doi.org/10.1093/toxsci/kfj017

Novak, I., 2012. Mitophagy: a complex mechanism of mitochondrial removal. Antioxidants \& Redox Signaling 17: 794-802. http:// dx.doi.org/10.1089/ars.2011.4407

Otteneder, H. and Majerus, P., 2000. Ochratoxin A in Kaffee: Bundesweite Auswertung von Daten der Lebensmittelüberwachung der Jahre 1995 bis 1999. Mycotoxin Research 16: 131-131. http://dx.doi.org/10.1007/BF02943000

Pagliassotti, M.J., Kim, P.Y., Estrada, A.L., Stewart, C.M. and Gentile, C.L., 2016. Endoplasmic reticulum stress in obesity and obesity-related disorders: an expanded view. Metabolism 65: 1238-1246. http://dx.doi.org/10.1016/j.metabol.2016.05.002

Park, S., Lim, W., You, S. and Song, G., 2019. Ochratoxin A exerts neurotoxicity in human astrocytes through mitochondriadependent apoptosis and intracellular calcium overload. Toxicology Letters 313: 42-49. http://dx.doi.org/10.1016/j. toxlet.2019.05.021

Perry, J.L., Goldsmith, M.R., Peterson, M.A., Beratan, D.N., Wozniak, G., et al. 2004. Structure of the ochratoxin A binding site within human serum albumin. The Journal of Physical Chemistry B 108: 16960-16964. http://dx.doi.org/10.1021/ jp0480652
Perry, J.L., Il'ichev, Y.V., Kempf, V.R., McClendon, J., Park, G., Manderville, R.A., Rüker, F., Dockal, M. and Simon, J.D., 2003. Binding of ochratoxin A derivatives to human serum albumin. The Journal of Physical Chemistry B 107: 6644-6647. http://dx. doi.org/10.1021/jp034284w

Petzinger, E. and Ziegler, K., 2000. Ochratoxin A from a toxicological perspective. Journal of Veterinary Pharmacology and Therapeutics 23: 91-98. http://dx.doi.org/10.1046/j.1365-2885. 2000.00244.x

Pfohl-Leszkowicz, A. and Manderville, R.A., 2007. Ochratoxin A: an overview on toxicity and carcinogenicity in animals and humans. Molecular Nutrition \& Food Research 51: 61-99. http://dx.doi.org/10.1002/mnfr.200600137

Pitt, J., 2000. Toxigenic fungi and mycotoxins. British Medical Bulletin 56: 184-192. http://dx.doi.org/10.1258/0007142001902888

Poor, M., Kuzma, M., Matisz, G., Li, Y., Perjesi, P., Kunsagi-Mate, S. and Kőszegi, T., 2014. Further aspects of Ochratoxin A-cation interactions: complex formation with zinc ions and a novel analytical application of ochratoxin A-magnesium interaction in the HPLC-FLD system. Toxins 6: 1295-1307. http://dx.doi. org/10.3390/toxins6041295

Qi, X., Yu, T., Zhu, L., Gao, J., He, X., Huang, K., et al. 2014. Ochratoxin A induces rat renal carcinogenicity with limited induction of oxidative stress responses. Toxicology and Applied Pharmacology 280: 543-549. http://dx.doi.org/10.1016/j.taap.2014.08.030

Ranaldi, G., Caprini, V., Sambuy, Y., Perozzi, G. and Murgia, C., 2009. Intracellular zinc stores protect the intestinal epithelium from Ochratoxin A toxicity. Toxicology in Vitro 23: 1516-1521. http://dx.doi.org/10.1016/j.tiv.2009.08.012

Ricci, F.G., Terkelli, L.R., Venancio, E.J., Justino, L., Dos Santos, B.Q., Baptista, A.A.S., et al. 2021. Tryptophan attenuates the effects of OTA on intestinal morphology and local IgA/IgY production in broiler chicks. Toxins 13: 5. http://dx.doi.org/10.3390/ toxins 13010005

Rindi, G., Klimstra, D.S., Abedi-Ardekani, B., Asa, S.L., Bosman, F.T., Brambilla, E., et al. 2018. A common classification framework for neuroendocrine neoplasms: an International Agency for Research on Cancer (IARC) and World Health Organization (WHO) expert consensus proposal. Modern Pathology 31: 1770-1786. http://dx.doi.org/10.1038/s41379-018-0110-y

Romani, S., Sacchetti, G., Chaves López, C., Pinnavaia, G.G. and Dalla Rosa, M., 2000. Screening on the occurrence of ochratoxin A in green coffee beans of different origins and types. Journal of Agricultural and Food Chemistry 48: 3616-3619. http://dx.doi. org/10.1021/jf990783b

Ropejko, K. and Twarużek, M., 2019. The occurrence of ochratoxin A in human body fluids-review. Toxin Reviews 23: 1-14. http:// dx.doi.org/10.1080/15569543.2019.1605530

Sava, V., Reunova, O., Velasquez, A., Harbison, R. and SanchezRamos, J., 2006. Acute neurotoxic effects of the fungal metabolite ochratoxin-A. Neurotoxicology 27: 82-92. http://dx.doi. org/10.1016/j.neuro.2005.07.004

Sava, V., Velasquez, A., Song, S. and Sanchez-Ramos, J., 2007. Adult hippocampal neural stem/progenitor cells in vitro are vulnerable to the mycotoxin ochratoxin-A. Toxicological Sciences 98: 187-197. http://dx.doi.org/10.1093/toxsci/kfm093 
Schaaf, G., Nijmeijer, S., Maas, R., Roestenberg, P., De Groene, E. and Fink-Gremmels, J., 2002. The role of oxidative stress in the ochratoxin A-mediated toxicity in proximal tubular cells. Biochimica et Biophysica Acta (BBA)-Molecular Basis of Disease 1588: 149-158. http://dx.doi.org/10.1016/ S0925-4439(02)00159-X

Schrickx, J., Lektarau, Y. and Fink-Gremmels, J., 2006. Ochratoxin A secretion by ATP-dependent membrane transporters in Caco-2 cells. Archives of Toxicology 80: 243-249. http://dx.doi. org/10.1007/s00204-005-0041-5

Seabra, A.B., Rolim, W.R. and Pieretti, J.C., 2020. Potent application of nitric oxide-releasing nanomaterials against toxigenic fungi and their mycotoxins. In: Nanomycotoxicology. Elsevier, pp. 481-501. http://dx.doi.org/10.1016/B978-0-12-817998-7.00020-3

Shen, X.L., Zhang, B., Liang, R., Cheng, W.-H., Xu, W., Luo, Y., et al. 2014. Central role of nix in the autophagic response to ochratoxin A. Food and Chemical Toxicology 69: 202-209. http://dx. doi.org/10.1016/j.fct.2014.04.017

Skaug, M.A., Helland, I., Solvoll, K. and Saugstad, O.D., 2001. Presence of ochratoxin A in human milk in relation to dietary intake. Food Additives \& Contaminants 18: 321-327. http://dx. doi.org/10.1080/02652030117740

Sorrenti, V., Di Giacomo, C., Acquaviva, R., Barbagallo, I., Bognanno, M. and Galvano, F., 2013. Toxicity of ochratoxin a and its modulation by antioxidants: a review. Toxins $5: 1742-$ 1766. http://dx.doi.org/10.3390/toxins5101742

Studer-Rohr, I., Schlatter, J. and Dietrich, D.R., 2000. Kinetic parameters and intraindividual fluctuations of ochratoxin A plasma levels in humans. Archives of Toxicology 74: 499-510. http:// dx.doi.org/10.1007/s002040000157

Sueck, F., Specht, J., Cramer, B. and Humpf, H.-U., 2019. Identification of ochratoxin-N-acetyl-L-cysteine as a new ochratoxin A metabolite and potential biomarker in human urine. Mycotoxin Research 36: 1-10. http://dx.doi.org/10.1007/ s12550-019-00360-0

Uetsuka, K., 2011. Mechanisms of mycotoxin-induced neurotoxicity through oxidative stress-associated pathways. International
Journal of Molecular Sciences 12: 5213-5237. http://dx.doi. org/10.3390/ijms12085213

van der Stegen, G.H., Essens, P.J. and van der Lijn, J., 2001. Effect of roasting conditions on reduction of ochratoxin A in coffee. Journal of Agricultural and Food Chemistry 49: 4713-4715. http://dx.doi.org/10.1021/jf0105586

Weidenbach, A., Schuh, K., Failing, K. and Petzinger, E., 2000. Ochratoxin A induced TNF $\alpha$ release from the isolated and blood-free perfused rat liver. Mycotoxin Research 16: 189-193. http://dx.doi.org/10.1007/BF02940035

Xing, Y., Yang, S.-D., Wang, M.-M., Feng, Y.-S., Dong, F. and Zhang, F., 2019. The beneficial roles of exercise training via autophagy in neurological diseases and possible mechanisms. Life Sciences 15:130-134 http://dx.doi.org/10.1016/j.lfs.2019.02.026

Xiong, K., Zhi, H.-W., Liu, J.-Y., Wang, X.-Y., Zhao, Z.-Y., Pei, P.-G., et al. 2020. Detoxification of ochratoxin A by a novel aspergillus oryzae strain and optimization of its biodegradation. Revista Argentina de Microbiología 53:48-54. http://dx.doi. org/10.1016/j.ram.2020.06.001

Yoon, S., Cong, W.-T., Bang, Y., Lee, S.N., Yoon, C.S., Kwack, S.J., et al. 2009. Proteome response to ochratoxin A-induced apoptotic cell death in mouse hippocampal HT22 cells. Neurotoxicology 30: 666-676. http://dx.doi.org/10.1016/j. neuro.2009.04.013

Yu, J., Mikiashvili, N. and Liang, C.L., 2019. Deoxynivalenol and ochratoxin A in North Carolina grown organic wheat grains. Journal of Food Safety e12687 5:17-170. http://dx.doi. org/10.1111/jfs.12687

Zhang, X., Boesch-Saadatmandi, C., Lou, Y., Wolffram, S., Huebbe, P. and Rimbach, G., 2009. Ochratoxin A induces apoptosis in neuronal cells. Genes \& Nutrition 4: 41. http://dx.doi. org/10.1007/s12263-008-0109-y

Zhu, L., Zhang, B., Dai, Y., Li, H. and Xu, W., 2017. A review: epigenetic mechanism in ochratoxin a toxicity studies. Toxins 9: 113. http://dx.doi.org/10.3390/toxins9040113 